\title{
Transcriptional and \\ Posttranscriptional Regulation of \\ Human Androgen Receptor \\ Expression by Androgen
}

\author{
Dieter A. Wolf*, Thomas Herzingert, Heiko Hermeking*, \\ Dorothea Blaschke, and Wolfram Hörz \\ Institute of Physiological Chemistry \\ University of Munich \\ D-8000 Munich 2, Germany
}

Autoregulation is a control mechanism common to several proteins of the steroid/thyroid hormone receptor superfamily. In this work the effect of androgens and antiandrogens on the expression of the human androgen receptor (hAR) in prostate and breast cancer cell lines was studied. Northern blot analysis revealed a decrease in hAR steady state RNA levels in LNCaP cells by $3.3 \mathrm{nM}$ of the synthetic androgen mibolerone. Maximal down-regulation of hAR RNA to $30 \%$ of control levels occurred $48 \mathrm{~h}$ after hormone addition. T47D breast cancer cells showed a similar effect with mibolerone, while hAR expression in normal skin fibroblasts did not respond to androgen treatment. As shown by nuclease S1 analysis, hAR transcripts initiate at three principal start sites, all of which are equally sensitive to androgen. Steroidal as well as nonsteroidal antiandrogens were capable of partially antagonizing androgen-mediated hAR RNA down-regulation in LNCaP and T47D cells, while not exerting a significant effect when administered alone. While hAR RNA stability was increased by hormone, nuclear run-on analysis revealed a 4-fold reduction of hAR gene transcription $96 \mathrm{~h}$ after androgen treatment. Although decreased hAR RNA levels did not coincide with a parallel decrease in AR protein levels, analysis of androgen-inducible reporter constructs demonstrated that prolonged androgen administration to cells results in a progressively impaired sensitivity of the intracellular androgen response mechanism. These results show that prolonged androgen exposure leads, besides its effect on hAR RNA levels, to functional inactivation of the AR. Thus, in vivo, posttranslational control of AR activity appears to be a novel mechanism of negative autoregulation of androgen effects on gene expression. (Molecular Endocrinology 7: 924-936 1993)

0888-8809/93/0924-0936\$03.00/0

Molecular Endocrinology

Copyright $\odot 1993$ by The Endocrine Society

\section{INTRODUCTION}

The androgen receptor (AR) is a member of the steroid and thyroid hormone receptor superfamily of ligandinducible transcription factors (for review see Ref. 1). Cotransfection experiments of AR CDNA with a reporter construct have shown that the AR mediates androgenregulated gene transcription $(2,3)$. By analogy with other steroid hormone receptors it is assumed that a complex between hormone and receptor is formed within the cell. A conformational change of this complex enables specific binding to recognition sequences near the promoter of the target gene to be activated. Modulation of the rate of transcription initiation is the ultimate result (for review see Refs. 4-6).

AR CDNAs have been cloned from various species (7-10). Comparative sequence analysis has revealed the typical domain structure (reviewed in Ref. 11), which is highly conserved among the members of the steroid hormone receptor family (4). Deletion mutagenesis has identified three functionally important regions: an amino terminal segment involved in transcriptional activation, a cysteine-rich DNA-binding domain, and a carboxyterminal hormone-binding domain. A nuclear translocation signal homologous to that found in the SV40 large $T$ antigen was recognized within the hinge region between the DNA- and steroid-binding domains (12).

The promoter regions of the human AR (hAR) and rat AR (rAR) genes lack typical TATA and CAAT sequence motifs but include a GC-rich region and contain putative Sp1 binding sites characteristic of housekeeping promoters. $\mathrm{S} 1$ nuclease protection analyses have demonstrated two major transcription initiation sites separated by few nucleotides, approximately 1.1 kilobases $(\mathrm{kb})$ upstream of the initiator methionine of the AR gene $(13,14)$.

Expression and regulation of the hAR and rAR genes have been investigated in cell lines and in animals. Significant expression of hAR RNA was detected in malignant breast (13), liver (15), and prostate cell lines (16), as well as in primary genital skin fibroblasts (13). in the rat ventral prostate $(15,17,18)$ and in the human 
prostate cancer cell line LNCaP, expression of AR RNA is regulated by androgens $(19,20)$. Androgen withdrawal increases and androgen administration decreases AR steady state RNA as assayed by Northern hybridization. In addition, in the human hepatoma cell line HepG2 and in the human mammary cancer cell line MFM-223 autologous down-regulation of AR RNA coincides with decreased AR protein levels $(15,21)$. These observations have led to the concept of negative autoregulation of AR expression in rat and human tissues analogous to that observed for other steroid hormone receptors (22-28). However, this hypothesis has remained controversial, since other studies, employing ligand-binding assays, have demonstrated positive autoregulation of AR protein levels in genital skin fibroblasts $(29,30)$. In contrast, by in situ hybridization and immunocytochemistry, Takeda et al. (18) have demonstrated up-regulation of both AR RNA and AR protein in the prostate of androgen-treated rats and mice. An even more complicated scenario has emerged from studies in $\mathrm{LNCaP}$ cells where androgen-dependent down-regulation of AR RNA appears to coincide with a transient 2-fold up-regulation of the AR protein (19). On the other hand, we reported recently that rapid protein synthesis-independent androgen induction of prostatespecific antigen (PSA) gene transcription in LNCaP cells takes a transient course, thereby pointing to a negative regulation of the androgen response pathway after long-term hormone administration (31).

In this study we have thoroughly reevaluated the effects of androgen on AR steady state RNA and protein levels in LNCaP cells. Moreover, we have performed experiments to study the hormonal regulation of AR expression with respect to hAR RNA metabolism, promoter usage, and transcriptional activity of the hAR gene, as well as subcellular localization and functional activity of the AR protein. We demonstrate that AR transcription from all mRNA initiation sites is negatively regulated by androgens in human prostate and breast cancer cell lines but not in normal human fibroblasts. Although hAR RNA down-regulation apparently does not coincide with reduced receptor protein levels or altered subcellular localization, androgen administration leads to functional desensitization of the intracellular hormone response mechanism in LNCaP and T47D cells as judged by the ability to activate androgenresponsive reporter gene constructs. Thus functional inactivation provides a novel mechanism of negative autoregulation of androgen action on gene expression.

\section{RESULTS}

\section{Effect of Androgen on AR Steady State RNA Levels}

To document the effect of androgens on hAR steady state RNA levels, the AR-containing cell line LNCaP (32) was treated for increasing periods of time with 3.3 $\mathrm{nM}$ of the nonmetabolizable synthetic androgen mibolerone (MIB) (33). RNA was analyzed on Northern blots probed with an hAR CDNA fragment. In LNCaP cells three major hAR RNAs of $11 \mathrm{~kb}, 8 \mathrm{~kb}$, and $4.7 \mathrm{~kb}$ are detectable (Fig. 1A). While the 11-kb RNA represents the full-length transcript containing all exons, the 8-kb RNA originates from the use of an alternative splice site thus leading to the loss of $3 \mathrm{~kb} 3^{\prime}$-untranslated sequences (14). The identity of the 4.7-kb RNA remains uncertain. It was proposed that the $4.7-\mathrm{kb}$ signal derives from unspecific hybridization of 285 ribosomal RNA (17). As shown in Fig. 1A, all three hAR transcripts continuously decrease with similar kinetics within 120 $\mathrm{h}$ of hormone incubation. Since equal amounts of total RNA were loaded on each gel lane, unspecific crosshybridization to 285 ribosomal RNA does not explain the disappearance of the 4.7-kb transcript after MIB treatment. Therefore the $4.7-\mathrm{kb}$ RNA probably represents a degradation product of the high molecular weight forms of hAR RNAs (14). However, this mRNA is still considerably longer than the protein coding part of the hAR cDNA [2730 base pairs (bp)], and therefore we cannot rule out a possible coding capacity of the 4.7-kb RNA.

Down-regulation of hAR RNA by MIB in LNCaP cells is down to $30 \%$ of control levels and is maximal after $48 \mathrm{~h}$ as compared to RNA levels simultaneously determined in the absence of MIB (Fig. 1B). Thus hAR RNA down-regulation in LNCaP cells is a delayed hormone effect. The RNA level of the gene for the glycolysis enzyme glyceraldehyde phosphate dehydrogenase (GAPDH) is not significantly influenced by MIB, and the corresponding RNA can thus be used to correct for unequal loading of RNA per lane.

To explore whether autologous down-regulation of the hAR gene is a phenomenon restricted to transformed LNCaP cells only, other normal and transformed human cells were analyzed. Normal genital skin fibroblasts (GSF) derived from infant foreskin as well as the human breast cancer cell line T47D express substantial amounts of hAR RNA (Fig. 1C). In T47D cells and GSF the major RNA species of $11 \mathrm{~kb}$ and $8 \mathrm{~kb}$ are detectable. The Northern blot in Fig. 1C moreover shows that, while hAR expression in T47D cells was equally sensitive to MIB, normal GSF showed no effect of MIB on hAR steady state RNA (Fig. 1C). The kinetics of hAR down-regulation in T47D cells were similar to the kinetics observed in LNCaP cells (data not shown).

\section{AR RNAs Starting from Different Transcription Initiation Sites are Equally Sensitive to Androgen}

Expression of the hAR gene uses a common promoter in diverse human tissues. Although, according to earlier reports $(13,14)$, the heterogeneity of transcription initiation described for a number of genes lacking canonical CAAT and TATA box sequences is also a property of the hAR gene, two major transcription initiation sites separated by few nucleotides have been recognized. Using a uniformly labeled single-stranded probe derived from the hAR upstream region, we have analyzed the hormone sensitivity of the different hAR RNA initiation 

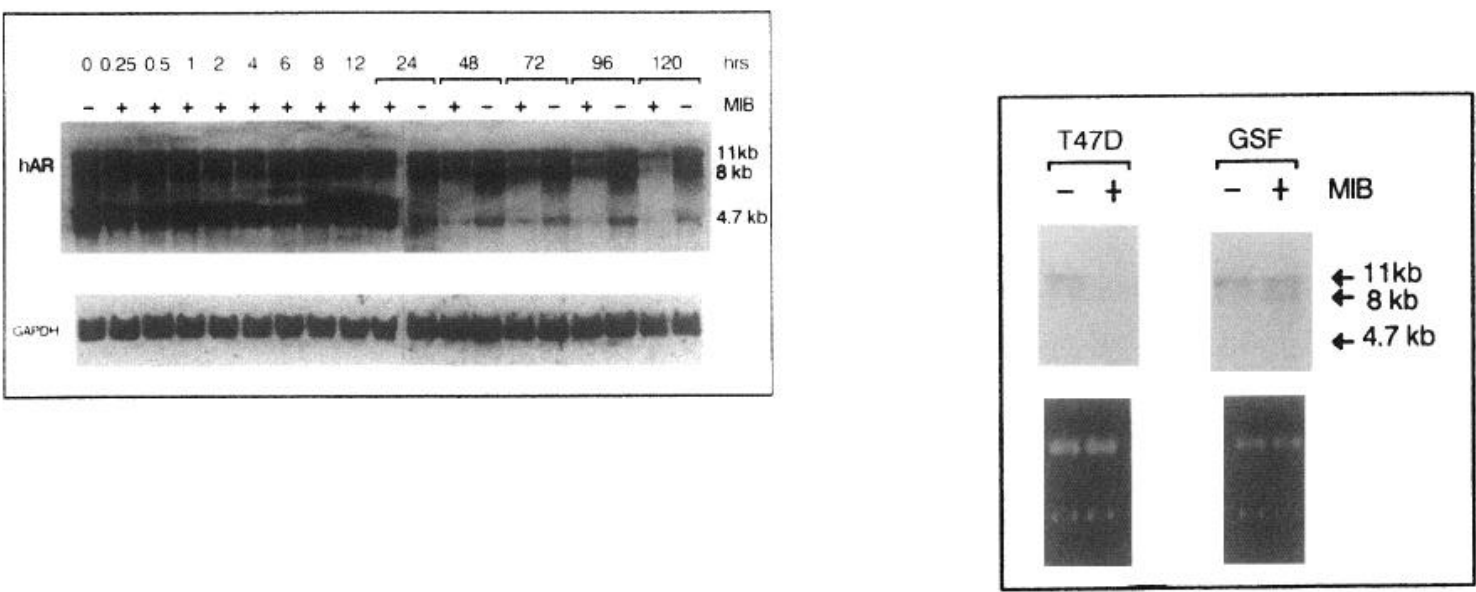

B

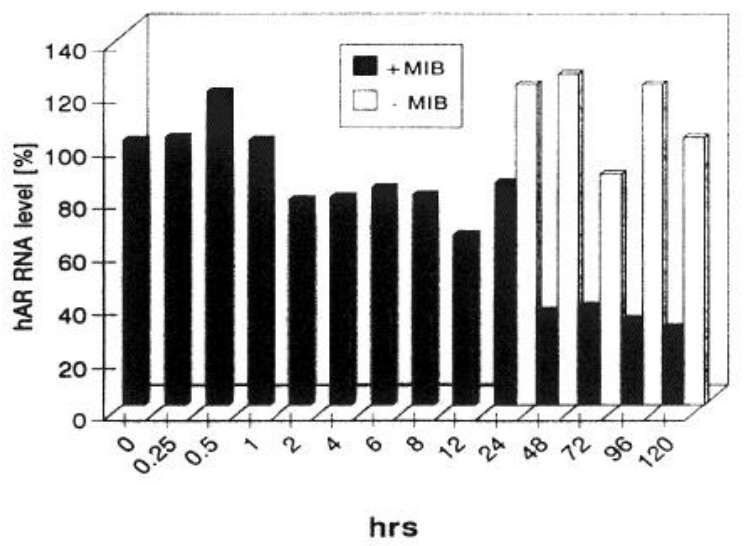

Fig. 1. Northern Blot Analysis of Total RNA of LNCaP, T47D, and GSF Cells after Treatment with the Synthetic Androgen MIB A, LNCaP cells were cultivated in the presence $(+)$ or absence $(-)$ of $3.3 \mathrm{nM}$ MIB for various periods from 0-120 $\mathrm{h}$. RNA was extracted and analyzed on Northern blots $(20 \mu \mathrm{g} / \mathrm{lane})$ hybridized with an hAR EcoRI/Pstl cDNA probe labeled by random priming. Subsequently the probe was washed off, and the filter was rehybridized with a probe for the housekeeping enzyme GAPDH (62). B. The autoradiograms were scanned densitometrically, and the results of hAR hybridization relative to GAPDH are shown schematically in a block diagram. C, T47D cells and GSFs were treated with MIB for $96 \mathrm{~h}$. Total cellular RNA was isolated, and fitters were hybridized with the hAR probe as in A. The ethidium bromide-stained gels before transfer are shown to document equal RNA loading per lane.

sites in a nuclease S1 protection assay. This seemed reasonable since the incomplete disappearance of hAR RNA even after prolonged hormone administration could reflect a differential effect of MIB on individual RNA start sites. We have recently observed differential effects of MIB on the promoter usage of the c-myc protooncogene in LNCaP cells (34).

Figure $2 \mathrm{~A}$ confirms the results of previous reports showing that hAR gene expression in several cell types uses two principal mRNA initiation sites located 1115 and 1126 nucleotides in front of the ATG translation initiation codon. The upstream and downstream start sites are referred to as 11 and 12 , respectively. In untreated $\mathrm{LNCaP}$ and T47D cells the relative usage of sites $11: 12$ is $1.5: 1$ as determined by densitometric scanning of the corresponding bands (data not shown). In addition to the 11 and 12 bands, a third, smaller band, 13 , is found which comprises $20 \%$ of the total hAR RNA.
Since 13 was not recognized in previous reports, we have mapped this start site relative to a sequencing reaction of this region starting from primer hAR 5 . It turned out to be 4-6 nucleotides downstream of 12 (Fig. $2 A)$. As can be gathered from Fig. $2 B$, the transcripts initiating from the three mRNA start sites are equally sensitive to autologous down-regulation by MIB in LNCaP and T47D cells but again not in GSF. Note that the internal ratio of start site usage does not change upon hormone addition (Fig. 2B). These results show that 11,12 , and 13 are subject to a common regulatory mechanism by androgens.

\section{Effect of Antiandrogens on AR RNA Expression}

Transduction of hormonal signals into the nucleus leading to modulation of gene expression is known to involve the hormone receptor protein. To evaluate the 
A
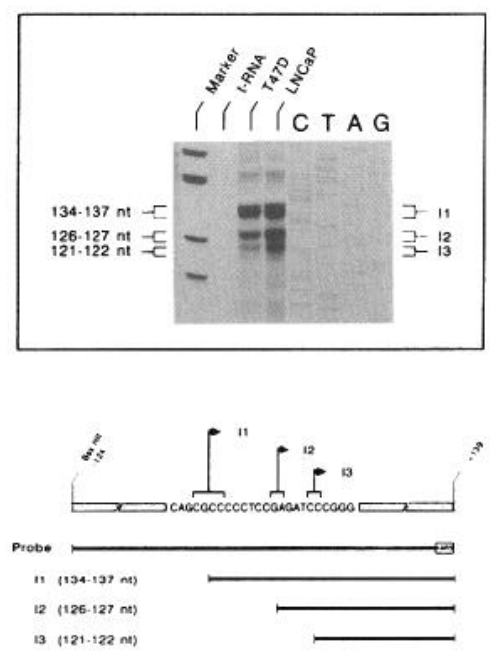

B

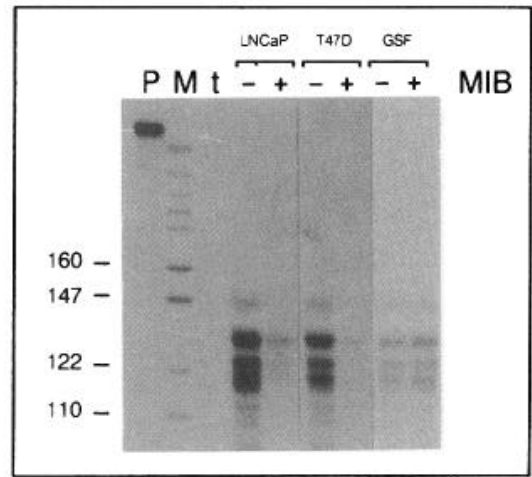

Fig. 2. Androgen Sensitivity of AR RNA Start Sites

A, Mapping of hAR RNA initiation sites by nuclease S1 protection assay with an antisense DNA probe derived from the hAR promoter region run in parallel with a sequencing reaction starting from primer hAR5. RNA derived from initiation site 1 (11) protected fragments of 134-137 bases, from 12 fragments of 126-127 bases, and from 13 fragments of 121122 bases. B, Several of the RNAs described in Fig. 1 were subjected to nuclease $\mathrm{S} 1$ analysis. P, Labeled DNA probe; M, molecular weight standard; t, yeast tRNA.

possible participation of the AR protein in hAR RNA down-regulation by MIB, we tried to antagonize the androgen effect by the simultaneous addition of AR blocking agents (antiandrogens). The steroidal antiandrogen cyproterone acetate (CA) as well as the nonsteroidal antiandrogen hydroxy flutamide (Flu-OH) were recently shown to effectively prevent the inhibitory action of MIB on proliferation and c-myc expression in LNCaP cells $(34,35)$ while not exerting any effect when administered alone. Due to the relatively low affinity of antiandrogens for the AR a several hundredfold molar excess over the androgen is required for effective blockage of androgen action (36).
Figure 3 again shows autologous down-regulation of hAR RNA by MIB. However, the simultaneous presence of $\mathrm{CA}$ or Flu-OH for $96 \mathrm{~h}$ partially abolishes the effect of MIB on all species of hAR steady state RNA. Antiandrogens alone have no significant effect on hAR RNA expression in LNCaP cells. Identical results were obtained for hAR regulation by antiandrogens in T47D cells (data not shown).

Quarmby et al. (17) recently reported drastic hAR down-regulation in LNCaP cells in response to the antiandrogen CA. To substantiate our contradictory findings, we have studied the effect of CA on hAR expression under more rigorous conditions. After downregulation of hAR RNA by treating LNCaP cells for 72 $h$ with MIB, the culture medium was renewed, an appropriate amount of CA but no MIB was added, and cells were harvested for RNA preparation after different periods. As shown in Fig. 3C, CA is not in a position to maintain the low level of hAR expression induced by MIB pretreatment for $72 \mathrm{~h}$. In contrast the presence of CA alone allows for the restoration of hAR RNA levels prevailing in untreated control cells. The kinetics of this reversion effect are similar to those obtained for autologous hAR down-regulation by MIB. Only 24-48 h after the addition of CA, pretreatment levels of hAR RNA are achieved. These results clearly demonstrate that hAR down-regulation in our stock of LNCaP cells is strongly antagonized by antiandrogens and thus in principle reversible. We conclude that the AR protein is involved in the process of autologous hAR regulation.

\section{AR RNA Down-Regulation by MIB Occurs at the Level of Transcription Initiation}

The AR is presumed to act as a transcription initiation modulator, but several in vivo studies of known androgen target genes have suggested that androgens primarily control RNA stability $(37,38)$. We therefore measured the effect of MIB on hAR RNA half-life. LNCaP control cells and cells incubated with MIB were treated with the RNA synthesis inhibitor actinomycin D $(5 \mu \mathrm{g} / \mathrm{ml})$ for different periods from 0-24 h. As shown in Fig. 4A, the half-life of the hAR RNA in untreated LNCaP cells is $3.8 \mathrm{~h}$. Preinduction of cells with MIB for $72 \mathrm{~h}$ increased hAR RNA half-life to $6.4 \mathrm{~h}$. Notably, an accelerated turnover of hAR RNA in the presence of MIB was not detectable in LNCaP cells (Fig. 4A), making a posttranscriptional mechanism of hAR RNA downregulation in LNCaP cells unlikely.

The fact that the AR protein is apparently involved in hAR RNA down-regulation without decreasing hAR RNA half-life prompted us to investigate the effect of androgens on hAR transcription. Autologous downregulation of the RNAs of various steroid hormone receptors was shown to occur at the level of transcription initiation $(23,26,28)$. Run-on analysis was performed in nuclei isolated from cells treated with MIB and/or CA for $96 \mathrm{~h}$. Nuclear transcripts were hybridized to strand-specific hAR CDNA probes. Probes for the PSA gene and the gene encoding phosphoglycerate 


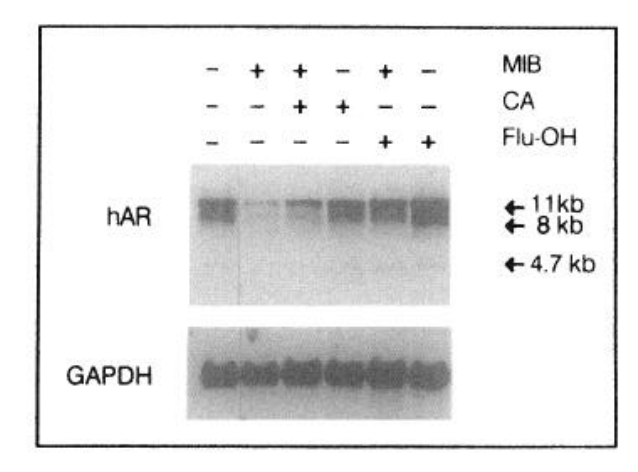

C

A
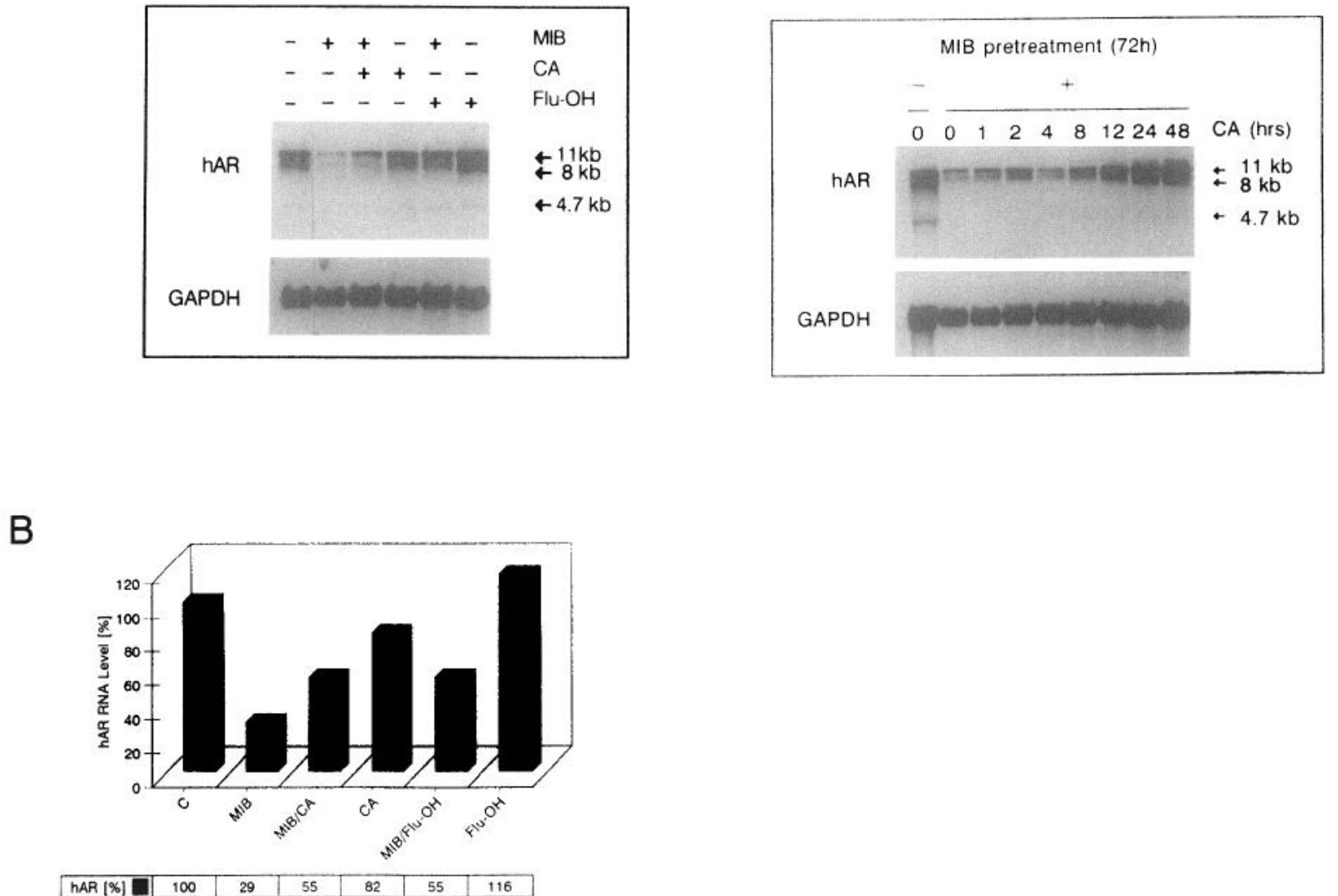

Fig. 3. Northern Blot Analysis of RNA of LNCaP Cells Treated with the Synthetic Androgen MIB and the Antiandrogen CA A, LNCaP cells were maintained in the presence $(+)$ or absence $(-)$ of $3.3 \mathrm{nM}$ MIB and $1.8 \mu \mathrm{M}$ CA or $2.6 \mu \mathrm{M}$ Flu-OH. RNA was isolated and analyzed on Northern blots $(20 \mu \mathrm{g} / \mathrm{lane})$ with the hAR probe. Filters were reprobed with GAPDH to correct for unequal loading of RNA per lane. B, Densitometric analysis of the blot presented in A. C, Effect of antiandrogen on hAR RNA levels after preincubation with MIB. LNCaP cells were maintained in the presence of $3.3 \mathrm{nM}$ MIB. After $72 \mathrm{~h}$ the medium was removed, and $1.8 \mu \mathrm{M}$ of CA but no MIB were added. RNA was isolated after different periods between 0 and $72 \mathrm{~h}$ and probed on Northern blots with the hAR probe.

kinase (PGK) were used as controls. As shown in Fig. $4 B$, significant hAR transcription in LNCaP cells is only observed on the coding strand. Treatment with MIB but not with the antiandrogen CA suppresses hAR transcription by $75 \%$ compared to untreated controls (scanning data not shown). Combined administration of MIB + CA largely prevents down-regulation of hAR transcription. The transcription rate for the PSA and PGK genes after $96 \mathrm{~h}$ is influenced by neither hormone treatment.

\section{Effect of Androgen on AR Protein Expression}

The results presented above demonstrate that androgens negatively regulate hAR RNA expression at the level of transcription initiation. Autologous down-regulation of progesterone and estrogen receptor RNAs was reported to correspond to reduced receptor protein levels $(24-26,28)$. In the human cancer cell lines HepG2 and MFM-233 as well as in the rat ventral prostate AR RNA down-regulation also leads to a decrease of AR protein $(15,17,21)$. In contrast Krongrad et al. (19) recently reported slightly increased AR protein levels early after androgen administration to LNCaP cells.

To see whether or not changes in hAR RNA result in altered protein expression under our culture conditions, total cellular proteins of LNCaP cells, T47D cells, and GSF were probed on immunoblots with the monoclonal antibody F39.4.1 (39) directed against the hAR. In LNCaP cells the antibody recognized two proteins migrating with an apparent mol wt of about $110 \mathrm{~K}$ as expected for the hAR (40) (Fig. 5). In T47D cells and in GSF the amount of receptor protein was obviously too low to be detected by this antibody. After $96 \mathrm{~h}$ of androgen treatment, i.e. at a time point at which hAR RNA down-regulation is maximal, the same amount of AR protein was detectable in androgen-treated vs. control samples of LNCaP cells. However, both protein bands migrated with a slightly slower mobility, suggesting a posttranslational modification. This result was confirmed in two independent experiments.

In order to be able to directly follow the intracellular 
A
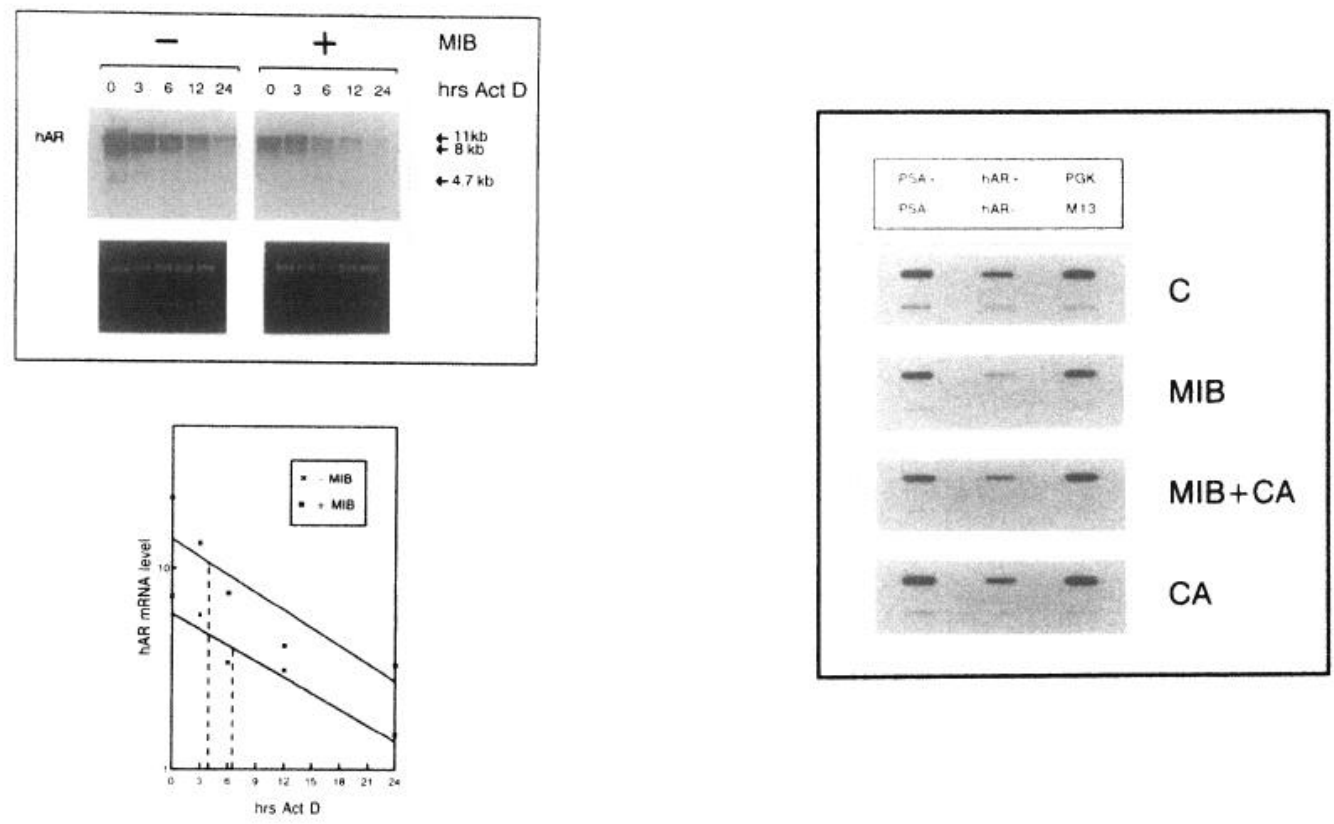

Fig. 4. Posttranscriptional and Transcriptional Regulation of the hAR Gene by MIB

A, Effect of MIB on hAR RNA half-life. Untreated LNCaP cells and cells treated with MIB for $72 \mathrm{~h}$ were incubated for various periods from 0-24 h with actinomycin $\mathrm{D}(5 \mu \mathrm{g} / \mathrm{ml})$, and RNA was isolated and subjected to Northern analysis by hybridization with an hAR CDNA probe. Autoradiograms were scanned, and hAR half-lives were calculated by regression analysis of absolute hAR RNA levels at each time point after actinomycin-D treatment. The ethidium bromide-stained gels before transfer are shown below the autoradiograms. B. Transcriptional regulation of the hAR gene by androgen and antiandrogen in LNCaP cells. Plasmids containing double-stranded and single-stranded DNA probes were transferred to nylon membranes by slot blot and hybridized with nuclear run-on RNA $\left(10^{7} \mathrm{cpm} / 3 \mathrm{ml}\right.$ hybridization buffer) from cells treated without or with MIB and/or CA for $96 \mathrm{~h}$. Probes detecting sense RNA are marked by + , those detecting antisense RNA by - .

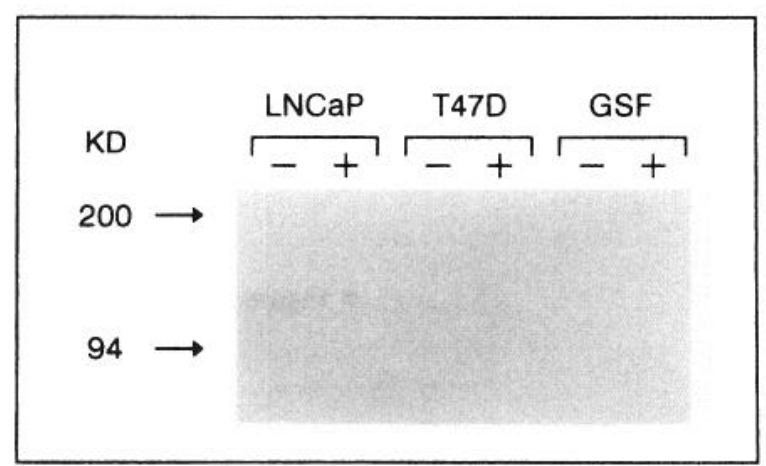

Fig. 5. Western Blot Analysis of AR Protein Expression

LNCaP cells, T47D cells, and GSFs were cultivated either in the presence $(+)$ or absence (-) of $3.3 \mathrm{nM}$ MIB for $96 \mathrm{~h}$, and total cellular proteins were isolated. Proteins were separated by sodium dodecyl sulfate-polyacrylamide gel electrophoresis, and immunological detection was performed using the monoclonal antibody F39.4.1 as described in Materials and Methods. AR protein expression in T47D cells and in GSF was too low to be detected by this antibody. dynamics of the AR, we carried out immunocytochemical analyses of AR protein expression in LNCaP cells treated with androgen for different periods. LNCaP cells, when maintained in the presence of $10 \%$ unmodified fetal calf serum (FCS), which contains approximately $0.1 \mathrm{~nm}$ testosterone and androstendione (41) [i.e. at least 100 -fold less than normal male sera (42)], showed predominantly nuclear staining of the AR (Fig. $6 B)$. While a recombinant AR expressed in COS cells was reported to be enriched in the perinuclear region of the cytoplasm before hormone addition $(12,43)$, nuclear staining in LNCaP cells was even preserved after maintenance in serum-free medium for $48 \mathrm{~h}$ (Fig. $6 \mathrm{~A})$. Addition of physiological amounts of androgen for various periods $(3-96 \mathrm{~h})$ resulted in neither a qualitative nor a significant quantitative change in AR staining (Fig. 6, C-F). In the AR-negative prostate cancer cell line DU145 (44) only slight background staining was observed (Fig. $6 \mathrm{H})$, as was the case with LNCaP control slides not incubated with the specific primary antibody (Fig. 6G). These results confirm and extend those of Krongrad et al. (19), demonstrating that, at least in LNCaP cells, hAR RNA down-regulation does not necessarily coincide with reduced protein levels or altered subcellular localization. 


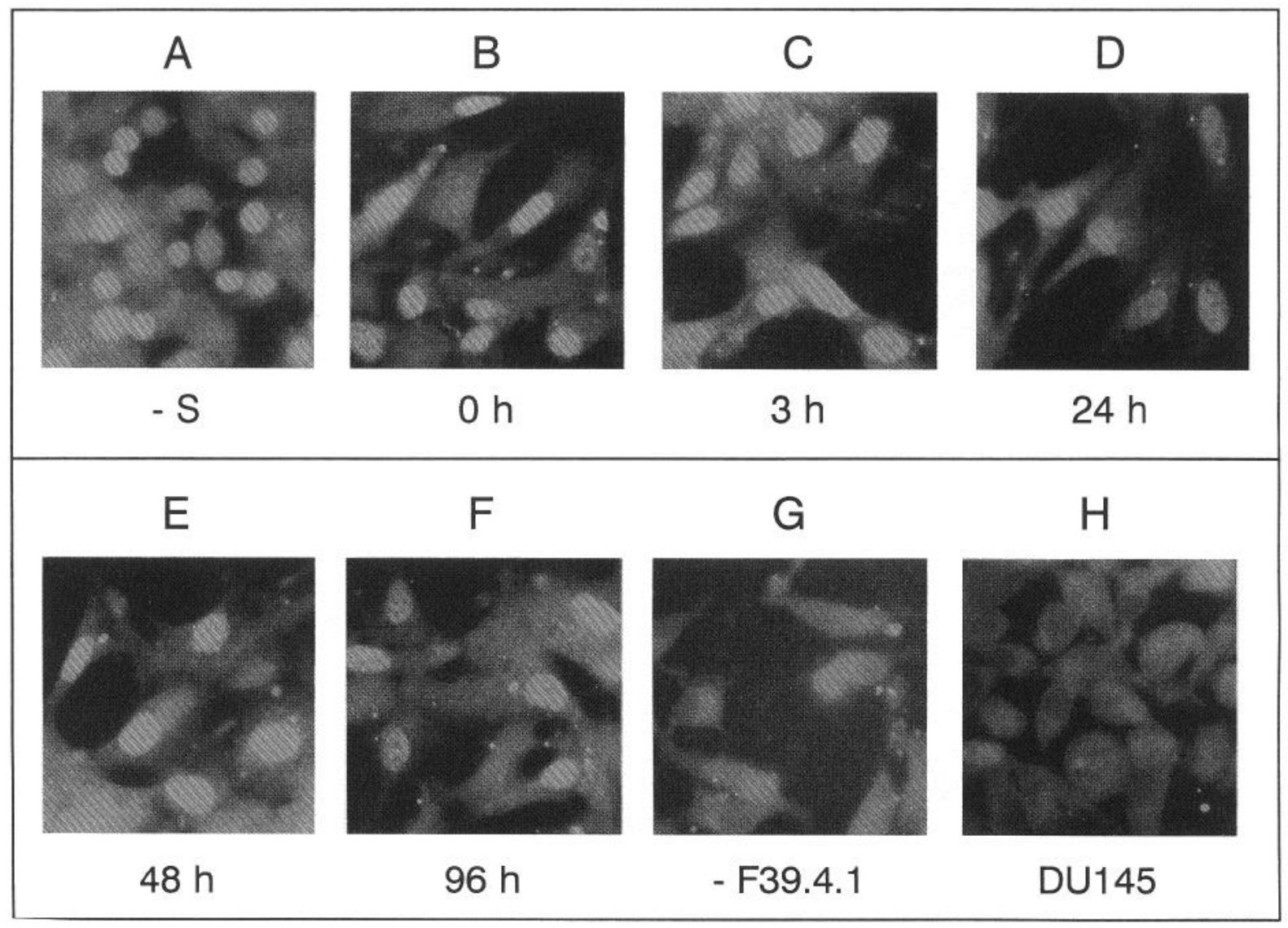

Fig. 6. Immunocytochemical Analysis of AR Protein Expression

LNCaP cells were maintained either in serum-free medium (A) or in medium containing $3.3 \mathrm{nM} \mathrm{MIB}$, cultivated for $0 \mathrm{~h}(\mathrm{~B}), 3 \mathrm{~h}(\mathrm{C})$, $12 \mathrm{~h}(\mathrm{D}), 48 \mathrm{~h}(\mathrm{E})$, and $96 \mathrm{~h}(\mathrm{~F})$, fixed, and processed for indirect immunofluorescent labeling using the monoclonal antibody F39.4.1. The AR-negative prostate cancer cell line DU145 $(\mathrm{H})$ and a sample of LNCaP cells not incubated with the specific primary antibody are used as controls $(\mathrm{G})$.

\section{Functional Inactivation of the AR after Prolonged Hormone Administration}

In previous reports we demonstrated that MIB rapidly and transiently increases PSA gene transcription in LNCaP cells $(31,34)$. Maximal induction occurred after $3 \mathrm{~h}$ and slowly declined toward pretreatment levels from 48 to $96 \mathrm{~h}$. From these kinetics we concluded that androgen-dependent PSA induction is a direct hormone effect involving the binding of the AR to an element present in the PSA promoter, closely resembling the consensus sequence for hormone response elements (31). Moreover, we speculated that the transient character of PSA induction might be due to inactivation of the intracellular hormone response mechanism. With regard to the parallel kinetics of PSA inducibility and hAR RNA levels, it seems intuitively logical to consider a numerical reduction of $A R$ molecules per cell as a consequence of hAR RNA down-regulation being responsible for this effect. However, the immunoblotting data presented above point to a functional inactivation of the AR after prolonged hormone administration in the presence of stable amounts of receptor proteins.
To test this hypothesis, we have cloned the natural PSA promoter in front of a promoterless chloramphenicol acetyltransferase (CAT) reporter plasmid and assayed for inducibility under various conditions of androgen treatment. The construct PSACAT61 was transfected by electroporation into LNCaP and T47D cells pretreated with MIB for increasing periods of time. Immediately after transfection duplicate dishes either did or did not receive $3.3 \mathrm{nM}$ MIB for $48 \mathrm{~h}$. In cells not preincubated with MIB, a 7- to 9-fold increase of CAT expression is found upon androgen stimulation (Fig. 7A), showing that the PSA promoter contains an androgen-inducible enhancer. However, with increased times of MIB preincubation in the range of 24-96 h, androgen inducibility of PSACAT61 in both cell lines decreases as compared to control levels simultaneously determined in the absence of hormone (Fig. 7A). CAT induction showed some variability during the first $48 \mathrm{~h}$ of hormone pretreatment but was consistently more than 5-fold reduced after $96 \mathrm{~h}$.

Since the PSA promoter fragment used for construction of PSACAT61 has an approximate length of $5 \mathrm{~kb}$, we could not rule out the possibility that numerical or 
A

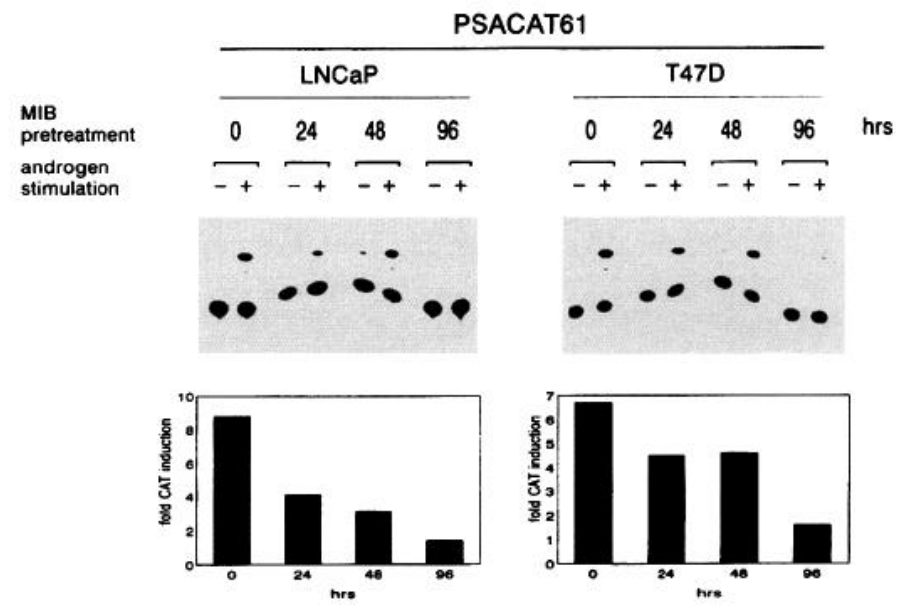

B

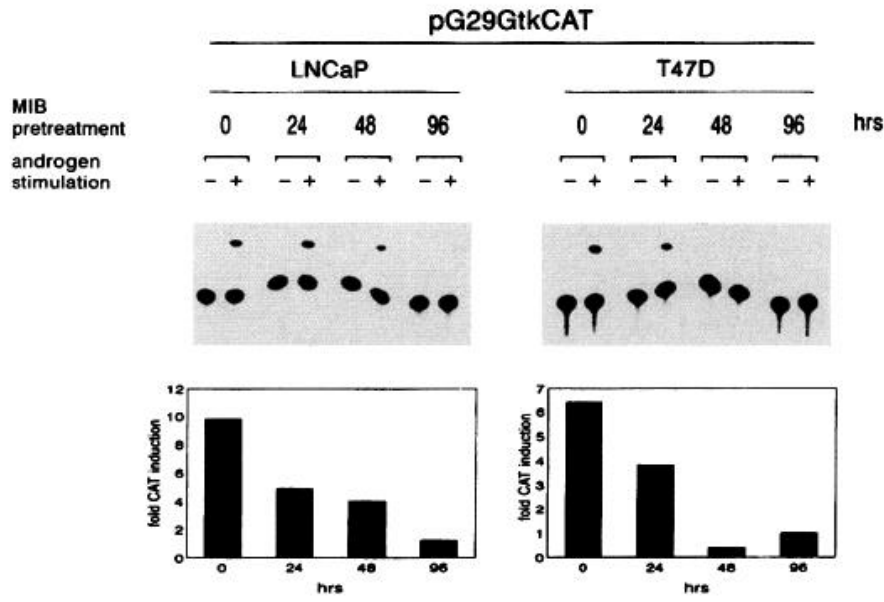

Fig. 7. Effect of MIB Pretreatment on Androgen Inducibility of PSACAT61 (A) and pG29GtkCAT (B) in LNCaP and T47D Cells

Duplicate cultures of cells pretreated with $3.3 \mathrm{nM}$ MIB for increasing periods from 0-96 $\mathrm{h}$ were transfected with $2.5 \mu \mathrm{g}$ of the respective plasmids and either stimulated or not by the addition of androgen for $48 \mathrm{~h}$. Protein extracts were prepared and assayed for CAT activity. TLC plates were autoradiographed, and autoradiograms were scanned. Scanning data are presented in a block diagram. The factor of CAT induction was calculated as CAT activity in the presence of hormone divided by CAT activity without androgen.

functional reduction of factors other than the AR is responsible for the self-limitation of androgen action on PSA transcription. We therefore performed control experiments with the plasmid G29GtkCAT which contains as sole androgen sensitive regulatory sequences two glucocorticoid/progesterone response elements spaced by 29 nucleotides directly in front of a thymidine kinase (tk) promoter-driven CAT construct (45). Again, in both cell lines, LNCaP and T47D, progressively reduced androgen inducibility was detectable depending on the duration of MIB pretreatment (Fig 7B). These results establish that, in vivo, prolonged androgen administration results in self-limitation of androgen-dependent trans-activation of androgen-sensitive promoters without any change in AR protein levels.

\section{DISCUSSION}

The phenomenon of negative autoregulation of the expression of genes encoding members of the steroid hormone receptor superfamily has previously been demonstrated for the estradiol receptor $(26,27)$, the progesterone receptor $(24,25,28)$, and the glucocorticoid receptor (GR) $(23,46,47)$. In this study we have analyzed in detail the hormonal regulation of the hAR with respect to promoter usage, RNA stability, rate of transcription, and trans-activating function.

\section{Androgen Regulation of hAR RNA Expression}

The mechanisms involved in autoregulation of other steroid receptor genes are diverse. While autologous 
down-regulation of the progesterone receptor, the estradiol receptor, and the GR genes occurs at the level of transcription initiation in some cell types $(23,26,28)$, the contribution of posttranscriptional mechanisms has been demonstrated in others (27). Negative autoregulation of the hAR gene in homogeneous cultures of human prostate cancer cells (LNCaP) is primarily a consequence of reduced transcriptional initiation at all mRNA start sites. In view of available sequence data, this finding is particularly interesting. Within $500 \mathrm{bp}$ upstream from the heterogeneous transcription initiation sites the promoter region of the rAR gene contains four repeats of the DNA-binding consensus sequence for steroid hormone receptors [hormone response element (HRE)] homologous to those found in other androgen-regulated genes (49). Given the high homology of the hAR and the rAR genes, the presence of HREs in the hAR gene promoter is possible. Unfortunately the published sequence of the hAR promoter region (13) does not extend to the region containing clustered HREs in the rat homolog, and a sequence comparison is thus impossible at present. Whether negative autoregulation of hAR gene transcription is mediated by HREs, as is hormone-dependent trans-activation (4), remains to be elucidated.

On the other hand, trans-repression of the gene encoding the transcription factor Fos is fundamentally different from Fos-mediated trans-activation. The c-fos gene is subject to autorepression (50), but the target site is not an AP1 binding motif but the serum response element (SRE) (51-53). Since repression via the SRE requires an intact Fos leucine repeat but no functional DNA-binding site (52), Fos is presumed to interact with another protein and inhibit transcription by competing for a factor needed for activation of the SRE. Transrepression of the collagenase I gene by the GR has also been shown to be independent of receptor DNA binding. In this case, trans-repression is mediated by direct protein-protein interaction between the DNAbinding domain of the GR and the DNA-binding region of a Jun monomer (54). Thus trans-repression by the AR may also differ from trans-activation in that it might be independent of HRE binding but involve interaction with another tissue-specific protein which is probably lacking in genital skin fibroblasts.

Data in favor of this model are provided by the analysis of antiandrogen action on hAR expression. The effects of antiandrogens on gene expression in LNCaP celis are particularly interesting, since a point mutation in the steroid-binding domain of the LNCaP cell hAR gene results in an altered hormone-binding specificity (55). Specifically, this mutation was shown to cause both increased receptor binding of CA compared to the wild type receptor and trans-activation of a reporter construct by $\mathrm{CA}$ via the mutated receptor $(56,57)$.

During recent years we have studied regulation by androgens and antiandrogens of three other genes in LNCaP cells. We demonstrated rapid transcriptional induction of kallikrein-like genes encoding PSA and human glandular kallikrein-1 (31) and delayed suppression of c-myc oncogene transcription in LNCaP cells by MIB (34). While antiandrogens prevented the androgen effect on c-myc transcription, CA acts as an androgen agonist on kallikrein gene transcription (31) and consequently fails to antagonize androgen induction. Thus antiandrogens act differentially on androgen-regulated gene transcription in LNCaP cells.

As in the case of c-myc transcription, CA is now shown also to antagonize the effect of MIB on hAR gene transcription and thus to behave as a classical antiandrogen, as does Flu-OH. This finding cannot be easily explained by the point mutation residing in the hAR gene of LNCaP cells. Since the wild type AR of T47D cells also mediates androgen-antagonistic activity of CA on hAR gene expression (data not shown), it appears that the mutated LNCaP AR behaves normally in transmitting CA signals on c-myc and hAR gene expression.

Androgen regulation of c-myc and hAR gene transcription has several features in common, which distinguishes it from kalikrein gene regulation: 1) c-myc and hAR genes are negatively regulated by androgens, whereas kallikrein genes are positively regulated; and 2) while kallikrein gene induction is a rapid event taking less than $3 \mathrm{~h}$ until maximal induction has occurred, $\mathrm{c}$ myc and hAR suppression is slow (>48 h). These differences may provide the basis for the differential effect of CA on androgen-regulated genes within one cell type.

Although the number of genes investigated is limited, it appears from our studies that CA antagonizes androgen effects in LNCaP cells when slow negative regulation is executed. The pathways involved in this type of regulation are expected to include additional, still unidentified mechanisms which, as a net result, mediate androgen-antagonistic activity of CA. In contrast, rapid positive regulation, as in the case of kallikrein genes, appears to be a direct hormone effect with a significant penetrance of the receptor point mutation leading to androgen-agonistic activity of CA. According to the model presented above, in LNCaP cells, the alteration of AR conformation induced by CA may be appropriate to allow binding to HREs and trans-activation but may be insufficient to mediate interaction with other regulatory proteins necessary for trans-repression.

\section{Androgen Regulation of hAR Protein Expression}

Direct action of androgen analogs on the transcription of the androgen-regulated PSA gene has been shown to be mediated via the HRE homologous sequence residing 150 bp upstream of the RNA initiation site (58). Although androgen analogs are metabolically stable over prolonged periods (59), PSA induction in LNCaP cells is transient $(48-96 \mathrm{~h})(31,34)$, indicating that androgen action is attenuated somewhere downstream of the ligand but upstream of the target sequence.

From the parallel kinetics of hAR RNA down-regulation and PSA inducibility one tentatively could infer that 
reduced RNA levels might result in decreased protein levels, thus accomplishing transience of PSA induction. As demonstrated by immunoblot analysis, this model, which may hold true for most steroid receptors in other cell systems $(15,21,24-26,28)$, proved too simple in the case of the AR in LNCaP cells. Maximal downregulation of hAR RNA after exposure to androgen for $96 \mathrm{~h}$ remains without a measurable effect on AR protein levels in LNCaP cells (Fig. 5). It thus appears that the principal aim of hAR gene regulation in LNCaP cells is to maintain constant AR protein levels over prolonged periods of androgen exposure. Since androgen administration is known to result in increased stability of the AR protein (43), the cell apparently has to activate a complex pattern of regulatory mechanisms including transcriptional shut-off of the hAR gene as well as posttranscriptional stabilization of hAR RNA (Fig. 4A) in order to keep AR protein levels constant.

The question remains, however, why, despite the presence of high amounts of receptor molecules as well as receptor ligand, the transcriptional inducibility of the androgen-regulated PSA gene is transient. The results presented in this study provide a key to understanding this process by the demonstration that, in vivo, downregulation of hAR RNA but not $\dot{A}$ R protein coincides with reduced inducibility of a reporter construct under the control of PSA regulatory sequences (Fig. 7A). Interestingly, a minimal promoter containing only two HREs is also subject to self-limited inducibility depending on the duration of hormone pretreatment (Fig. 7B), demonstrating that the AR protein is functionally impaired in LNCaP and T47D cells treated with hormone for prolonged periods. A similar observation was very recently reported by Hackenberg et al. (21) in another human breast cancer cell line. Thus posttranslational control may be the actual mechanism of self-limitation of androgen effects on gene expression.

Within the particular signal transduction pathway activated by steroid hormones (reviewed in Refs. 4,6 ), several explanations for the self-limitation of receptormediated effects on gene expression are conceivable. Upon passively entering the cell, the hormone binds to its homologous receptor. As a consequence of hormone binding the receptor dissociates from heat shock proteins, a process which enables homodimerization, heterooligomerization with other proteins, and binding to target sequences on the DNA, eventually resulting in trans-activation or trans-repression of responsive promoters. Constant levels of receptor proteins and ligand provided posttranslational autoregulation of receptor activity is theoretically possible at several levels: nuclear translocation, heat shock protein interaction, receptor dimerization, oligomerization with other proteins, DNA binding, and transactivation potential. While it has already been shown that phosphorylation of the AR in response to hormone administration is a potential form of posttranslational modification $(43,60)$, our studies rule out the model that this modification might alter the subcellular localization of the AR, which in turn could lead to nuclear exclusion and consequent impairment of trans-activating function.

In conclusion, this study uncovers a novel level of AR regulation and indicates that a complex pattern of transcriptional and posttranscriptional mechanisms operates in LNCaP cells to bring about fine tuning of the homeostasis of receptor-mediated androgen effects on gene expression.

\section{MATERIALS AND METHODS}

\section{Cell Culture and Hormones}

The human prostate cancer cell line LNCaP (32) was from the Human Cancer Cell Laboratory, Sloan Kettering Institute for Cancer Research (Rye, NY). LNCaP cells between passages 70 and 80 were used for the experiments described. LNCaP cells were maintained in RPMI 1640 as monolayers in the presence of $10 \% \mathrm{FCS}$ and $2 \mathrm{mM}$ glutamine as described (35). The human breast cancer cell line T47D (61) was kindly provided by Dr. R. Renkawitz (University of Giessen, Giessen, Germany). T47D cells were cultivated in Dulbecco's modified Eagle's medium containing $10 \% \mathrm{FCS}$ and $2 \mathrm{~mm}$ glutamine. GSFs were isolated from primary cultures of human foreskin keratinocytes. Infant foreskins obtained by routine circumcision were freed from adjacent blood vessels and placed on a trypsin/EDTA solution (0.25\% trypsin/0.05\% EDTA) in PBS devoid of $\mathrm{Ca}^{2+}$ and $\mathrm{Mg}^{2+}$ at $4 \mathrm{C}$ for $21 \mathrm{~h}$. Cells were separated from the upper side of the dermis and filtered through sterile gauze into a $0.01 \%$ solution of soybean trypsin inhibitor in PBS. After centrifugation at $1000 \mathrm{rpm}$ for $5 \mathrm{~min}$, the cells were resuspended in serum-free keratinocyte medium (GIBCO, Grand Island, NY) containing $5 \mu \mathrm{g} /$ liter epidermal growth factor, $50 \mathrm{mg} /$ /iter bovine pituitary extract and gentamicin, and seeded into tissue culture flasks. Upon reaching approximately $75 \%$ confluency, the medium was removed, and the cells were washed twice with $\mathrm{Ca}^{2+} / \mathrm{Mg}^{2+}$-free PBS and incubated in $2 \mathrm{mi}$ trypsin/EDTA solution (0.025\% trypsin/0.02\% EDTA) for $2 \mathrm{~min}$ at $37 \mathrm{C}$. During that period the fibroblasts detach first as they are less adherent to the substratum than the keratinocytes. Cells were aspirated and suspended in Dulbecco's modified Eagle's medium containing $10 \%$ FCS and 2 mM glutamine.

For the preparation of seed stocks, cells were grown to 50 $75 \%$ confluency before use. Hormones were added $48 \mathrm{~h}$ after seeding as ethanol solutions. Final concentrations of the hormones were $3.3 \mathrm{nM}$ for the synthetic androgen MIB (Upjohn, Kalamazoo, Ml), $1.8 \mu \mathrm{M}$ for the antiandrogen CA (Schering $\mathrm{AG}$, Berlin, Germany) and $2.6 \mu \mathrm{M}$ for the antiandrogen Flu-OH (Essex). Actinomycin D (Boehringer Mannheim, Mannheim, Germany) was used at a final concentration of $5 \mu \mathrm{g} / \mathrm{ml}$.

\section{RNA Extraction and Northem Blot Analysis}

Standard protocols were followed as described elsewhere (35). Autoradiograms were scanned in an LKB (Bromma, Sweden) UlitraScan XL Laser Densitometer.

\section{Hybridization Probes and Plasmids}

${ }^{32} \mathrm{P}$ Labeling was performed with a random-primed labeling kit (Boehringer Mannheim) according to the recommendations of the supplier. The 450-bp EcoRI/Pstl cDNA fragment used as an hAR probe for Northern analyses was generated by polymerase chain reaction from reverse-transcribed total cellular RNA isolated from LNCaP cells. The probe covers sequences encoding parts of the hormone-binding domain and the $3^{\prime}$ untranslated region. The probe for the housekeeping enzyme GAPDH was a synthetic single-stranded oligonucleotide (100 
bases) derived from the published sequence (62) and was endlabeled with polynucleotide kinase.

For the nuclear run-on transcription assays the plasmid pSVARo (kindly provided by J. Trapman, Erasmus University, Rotterdam. The Netherlands) was digested with Hindlll and Pstl (positions 1850-3002 according to Ref. 63), and the resulting 1.15-kb fragment was subcloned in both orientations into M13 mpt8 and mp19 phages. The probe for PSA was an EcoRI CDNA fragment spanning the complete coding region for the mature PSA protein (64). The probe for the gene encoding PGK was a 1.8-kb cDNA subcloned in pBA 328 (65).

The template for the AR probe used in the nuclease $S 1$ protection assays was amplified from $1 \mu \mathrm{g}$ genomic DNA from LNCaP cells by the polymerase chain reaction. The primer hAR3 corresponded to nucleotides -300 to -278 and the primer hAR5 to nucleotides 119-139 relative to 12 (numbered according to Ref. 13). The resulting 438-bp fragment, termed PAR1, was cloned into M13 mp18 (M13PAR1).

The PSACAT61 plasmid used in DNA transfection assays was generated by inserting a genomic Hindlll fragment containing the genuine PSA promoter in addition to $5 \mathrm{~kb}$ PSA upstream sequences into the promoterless CAT reporter plasmid pBLCAT6 (generously provided by G. Schütz, Deutsches Krebs-Forschungzentrum, Heidelberg, Germany). The androgen-inducible control plasmid G29GtkCAT contains two progesterone/glucocorticoid response elements upstream from a herpes simplex virus tk promoter-driven CAT construct (45) and was kindly provided by $R$. Renkawitz.

\section{S1 Nuclease Protection Assay}

A single-stranded uniformly labeled DNA probe was prepared by primer extension of M13PAR1 in the presence of $\left[\alpha^{32} \mathrm{P}\right]$ deoxy-ATP and $\left[\alpha^{32}\right.$ P]deoxy-CTP. The extended products were digested with the restriction endonuclease BssHII, and the labeled probe was separated from the M13 template on a $5 \%$ denaturing polyacrylamide gel. The probe was detected by autoradiography and eluted with $0.5 \mathrm{M}$ ammonium acetate, $10 \mathrm{~mm}$ magnesium acetate, and $10 \mathrm{~mm}$ EDTA $(\mathrm{pH} 8.0)$ for $8 \mathrm{~h}$ at $37 \mathrm{C}$. Hybridization of labeled DNA fragments to total RNA was carried out using a modification of the method of Berk and Sharp (66). Hybridization mixtures of $20 \mu$ l containing $5 \times$ $10^{4} \mathrm{cpm}$ of the labeled antisense probe, $30 \mu \mathrm{g}$ (LNCaP) or 60 $\mu \mathrm{g}$ (T47D and GSF) RNA, $80 \%$ formamide, $400 \mathrm{~mm} \mathrm{NaCl}, 40$ mM piperazine-N, $N^{\prime}$-bis(2-ethanesulfonic acid), $\mathrm{pH} 6.5$, and 1 $\mathrm{mm}$ EDTA were denatured at $90 \mathrm{C}$ for $5 \mathrm{~min}$ and immediately transferred to $52 \mathrm{C}$. After $15 \mathrm{~h}$ the hybridization was terminated by addition of $180 \mu$ lice-cold buffer containing $250 \mathrm{~mm} \mathrm{NaCl}$, $30 \mathrm{~mm}$ Na-acetate, pH 4.5, $2 \mathrm{~mm} \mathrm{Zn-acetate,} \%$ glycerol, and $400 \mathrm{U}$ nuclease $\mathrm{S} 1$ (Boehringer Mannheim). After incubating the samples at $42 \mathrm{C}$ for $1 \mathrm{~h}$, the reaction was stopped by the addition of $50 \mu / 4 \mathrm{M}$ ammonium actetate, $50 \mathrm{~mm}$ EDTA, and $50 \mu \mathrm{g} / \mathrm{ml}$ yeast tRNA, and the nucleic acid was precipitated with ethanol. Protected DNA fragments were separated on $7 \%$ polyacrylamide gels containing $7 \mathrm{M}$ urea. Gels were dried and exposed to Fuji (Tokyo, Japan) X-ray films for 8-12 h between intensifying screens at $-80 \mathrm{C}$.

\section{Nuclear Run-On Analysis}

Preparation of cell nuclei and hybridization were performed as described (34). Filters were exposed to Fuji X-ray films between DuPont (New England Nuclear, Boston, MA) Lightning Plus intensifying screens for 3 days.

\section{Immunoblotting}

Cellular proteins were isolated according to Sambrook et al. (67) and stored in aliquots at $-80 \mathrm{C}$ until use. Equal amounts of protein $(80 \mu \mathrm{g} / \mathrm{lane})$ were passed through a $4 \%$ stacking gel and separated in an $8 \%$ resolution gel. After electrophoresis gels were blotted onto nylon membranes (Millipore, Bed- ford, MA; Immobilon-P) using an electroblot apparatus operating at $35 \mathrm{~mA}$ for $12 \mathrm{~h}$. Membranes were blocked by two sequential incubations in 5\% low-fat powdered milk (dissolved in PBS) for 90 min each. Filters were incubated with a 1:100 dilution of the hAR antibody F39.4.1 (39) (Monosan, Uden. The Netherlands) for $3 \mathrm{~h}$ at room temperature on a rocking platform and for an additional $8 \mathrm{~h}$ at $4 \mathrm{C}$ without shaking. Unbound antibody was removed by five washes, 10 min each, in PBS/ $0.1 \%$ Tween 20 at room temperature. Incubation with a peroxidase-conjugated antimouse immunoglobulin $\mathbf{G}$ antibody was performed at room temperature for $2 \mathrm{~h}$ on a rocking table. After five washes in PBS $/ 0.1 \%$ Tween 20 , immunoreactive bands were visualized by incubation in $80 \mathrm{ml}$ of a PBS solution containing $30 \mathrm{mg}$ diaminobenzidine (Sigma, St. Louis, MO) and $30 \mu \mathrm{H}_{2} \mathrm{O}_{2}$. After achieving maximal band intensity filters were rinsed in distilled water and photographed.

\section{Immunocytochemistry}

LNCaP cells were seeded onto glass cover slips in the absence or presence of FCS and/or 3.3 nM MIB. After different times cells were washed twice in PBS and fixed for 30 min at $4 \mathrm{C}$ in $2 \%$ paraformaldehyde. Cells were washed and incubated in PBS containing $0.01 \%$ saponine (Sigma) and $0.01 \%$ sodium azide for $15 \mathrm{~min}$. Cells were incubated for $1 \mathrm{~h}$ at $37 \mathrm{C}$ with a 1:10 dilution of the monoclonal antibody F39.4.1 in PBS/ saponine, followed by three washes in PBS/saponine. The tetramethylmodamine $B$ isothiocyanate-labeled secondary antimouse immunoglobulin $G$ antibody was used at a 1:40 dilution for $45 \mathrm{~min}$ at $37 \mathrm{C}$. After 2 washes in PBS/saponine and two washes in PBS alone, cover slips were prepared for fluorescent microscopy, and representative sections were photographed at a 400 -fold magnification.

\section{DNA Transfection and Assay for CAT Activity}

DNA transfection was performed by electroporation using a Bio-Rad (Richmond, CA) Gene Pulser operating at 300 V (960 microfarads). Cells were preincubated with $3.3 \mathrm{nM} \mathrm{MIB}$ for various periods (time points indicated in Fig. 7). After the preincubation period cell numbers were adjusted to $5 \times 10^{6}$ cells per sample suspended in $800 \mu$ l culture medium in an electroporation cuvette; $2.5 \mu \mathrm{g}$ of each reporter plasmid were added for transfection. To assure equal transfection efficiencies, samples were devided into two equal parts ( $400 \mu$ leach) after transfection and were seeded on two $10-\mathrm{cm}$ dishes, one of which received hormone ( $3.3 \mathrm{nM}$ MIB) immediately after seeding. Cells were harvested $48 \mathrm{~h}$ after transfection for preparation of CAT extracts.

Preparation of extracts and assay for CAT activity was performed according to Sambrook et al. (67). Briefly, cells were scraped from the culture dish with a rubber policeman, washed twice in PBS, and resuspended in $100 \mu 10.25 \mathrm{M}$ Tris/ $\mathrm{HCl}$, pH 7.6. Cells were tysed by two repeated cycles of freezing $(-80 \mathrm{C})$ and thawing $(4 \mathrm{C})$, cell detritus was spun down at $12,000 \mathrm{rpm}$ for $10 \mathrm{~min}$ at $4 \mathrm{C}$, and the supernatant was transferred into a new tube. Fifty microliters of extract were incubated at $55 \mathrm{C}$ for $15 \mathrm{~min}$ and added to $50 \mu \mathrm{l} 1 \mathrm{M}$ Tris $/ \mathrm{HCl}, \mathrm{pH} 7.4,20 \mu$ lacetyl coenzyme A $(3.5 \mathrm{mg} / \mathrm{ml}$, freshly prepared), and $10 \mu l\left[{ }^{14} \mathrm{C}\right]$ chloramphenicol $(0.1 \mathrm{mCi} / \mathrm{ml})$, and the reaction was incubated at $37 \mathrm{C}$ for $2 \mathrm{~h}$. One milliliter of ethyl acetate was added, mixed by vigorous vortexing, and centrifuged for $5 \mathrm{~min}$ at room temperature. The supernatant was evaporated under vacuum and reaction products were redissolved in $30 \mu$ l ethyl acetate, $20 \mu$ l of which were applied to the origin of a silica gel TLC plate. Plates were run in chloroform/methanol $(95 / 5$, vol/vol), dried, and exposed to Fuji $\mathrm{X}$-ray films for $12 \mathrm{~h}$. The spots corresponding to the monoacetylated forms of chloramphenicol were measured with a thinlayer scanner, and the total amount of $\left[{ }^{14} \mathrm{C}\right]$ acetyl-chloramphenicol was calculated from the area under the resulting peak. 


\section{Acknowledgments}

We thank Drs. G. Schütz, R. Renkawitz, and J. Trapman for providing plasmids and cell lines and Dr. D. Eick for carefully reading the manuscript.

Received September 4, 1992. Rerevision received April 20, 1993. Accepted May 11, 1993.

Address requests for reprints to: Dieter A. Wolf, Institut für Klinische Molekularbiologie und Tumorgenetik, Marchioninstrasse 25, D-8000 München 70, Germany.

This work was supported by the Deutsche Forschungsgemeinschaft.

"Present address: Institut für Klinische Molekularbiologie und Tumorgenetik, GSF Forschungszentrum für Umwelt und Gesundheit, Marchioninistrasse 25, D-8000 München 70, Germany.

† Present address: Dermatologische Klinik und Poliklinik der Universität München, Frauenlobstrasse 9-11, D-8000 München 2, Germany.

\section{REFERENCES}

1. Evans RM 1988 The steroid and thyroid hormone receptor superfamily. Science 240:889-895

2. Rundlett SE, Wu XP, Miesfeld RL 1990 Functional characterizations of the androgen receptor confirm that the molecular basis of androgen action is transcriptional regulation. Mol Endocrinol 4:708-714

3. Quarmby VE, Kemppainen JA, Sar M, Lubahn DB, French FS, Wilson EM 1990 Expression of recombinant androgen receptor in cultured mammalian cells. Mol Endocrinol 4:1399-1407

4. Beato $M 1989$ Gene regulation by steroid hormones. Cell 56:335-344

5. O'Malley B 1990 The steroid receptor superfamily: more excitement predicted for the future. Mol Endocrinol 4:363-369

6. Fuller PJ 1991 The steroid receptor superfamily-mechanisms of Diversity. FASEB J 5:3092-3099

7. Chang CS, Kokontis J, Liao ST 1988 Molecular cloning of human and rat complementary DNA encoding androgen receptors. Science 240:324-326

8. Lubahn DB, Joseph DR, Sullivan PM, Willard HF, French FS, Wilson EM 1988 Cloning of human androgen receptor complementary DNA and localization to the $X$ chromosome. Science 240:327-330

9. Trapman J, Klaassen P, Kuiper GG, van der Korput JA, Faber PW, van Rooij HC, Geurts van Kessel A, Voorhorst MM, Mulder E, Brinkmann AO 1988 Cloning, structure and expression of a CDNA encoding the human androgen receptor. Biochem Biophys Res Commun 153:241-248

10. He WW, Fischer LM, Sun S, Bilhartz DL, Zhu XP, Young CY, Kelley DB, Tindall DJ 1990 Molecular cloning of androgen receptors from divergent species with a polymerase chain reaction technique: complete CDNA sequence of the mouse androgen receptor and isolation of androgen receptor cDNA probes from dog, guinea pig and clawed frog. Biochem Biophys Res Commun 171:697-704

11. Liao SS, Kokontis J, Sai T, Hiipakka RA 1989 Androgen receptors: structures, mutations, antibodies and cellular dynamics. J Steroid Biochem 34:41-51

12. Simental JA, Sar M, Lane MV, French FS, Wilson EM 1991 Transcriptional activation and nuclear targeting signals of the human androgen receptor. J Biol Chem 266:510-518

13. Tilley WD, Marcelli M, McPhaul MJ 1990 Expression of the human androgen receptor gene utilizes a common promoter in diverse human tissues and cell lines. J Biol Chem 265:13776-13781

14. Faber PW, van Rooij HC, van der Korput HA, Baarends WM, Brinkmann AO, Grootegoed JA, Trapman J 1991 Characterization of the human androgen receptor transcription unit. J Biol Chem 266:10743-10749

15. Shan LX, Rodriguez MC, Jänne OA 1990 Regulation of androgen receptor protein and mRNA concentrations by androgens in rat ventral prostate and seminal vesicles and in human hepatoma cells. Mol Endocrinol 4:16361646

16. Tilley WD, Wilson CM, Marcelli M, McPhaul MJ 1990 Androgen receptor gene expression in human prostate carcinoma cell lines. Cancer Res 50:5382-5386

17. Quarmby VE, Yarbrough WG, Lubahn DB, French FS, Wilson EM 1990 Autologous down-regulation of androgen receptor messenger ribonucleic acid. Mol Endocrinol 4:22-28

18. Takeda $H$, Nakamoto T, Kokontis J, Chodak GW, Chang C 1991 Autoregulation of androgen receptor expression in rodent prostate: immunohistochemical and in situ hybridization analysis. Biochem Biophys Res Commun $177: 488-496$

19. Krongrad A, Wilson CM, Wilson JD, Allman DR, McPhaul MJ 1991 Androgen increases androgen receptor protein while decreasing receptor mRNA in LNCaP cells. Mol Cell Endocrinol 76:79-88

20. Trapman J, Ris Stalpers C, van der Korput JA, Kuiper GG, Faber PW, Romijn JC, Mulder E, Brinkmann AO 1990 The androgen receptor: functional structure and expression in transplanted human prostate tumors and prostate tumor cell lines. J Steroid Biochem Mol Biol 37:837-842

21. Hackenberg R, Hawighorst T, Filmer A, Slater EP, Bock K, Beato M. Schulz K-D 1992 Regulation of androgen receptor mRNA and protein levels by steroid hormones in human mammary cancer cells. J Steroid Biochem Mol Biol 43:599-607

22. Okret S, Poellinger L, Dong Y, Gustafsson JA 1986 Downregulation of glucocorticoid receptor mRNA by glucocorticoid hormones and recognition by the receptor of a specific binding sequence within a receptor CDNA clone. Proc Natl Acad Sci USA 83:5899-5903

23. Rosewicz S, McDonald AR, Maddux BA, Goldfine ID, Miesfeld RL, Logsdon CD 1988 Mechanism of glucocorticoid receptor down-regulation by glucocorticoids. J Biol Chem 263:2581-2584

24. Wei LL, Krett NL, Francis MD, Gordon DF, Wood WM, O'Malley BW, Horwitz KB 1988 Multiple human progesterone receptor messenger ribonucleic acids and their autoregulation by progestin agonists and antagonists in breast cancer cells. Mol Endocrinol 2:62-72

25. Read LD, Snider CE, Miller JS, Greene GL, Katzenellenbogen BS 1988 Ligand-modulated regulation of progesterone receptor messenger ribonucleic acid and protein in human breast cancer cell lines. Mol Endocrinol 2:263-271

26. Saceda M, Lippman ME, Chambon P, Lindsey RL, Ponglikitmongkol M, Puente M, Martin MB 1988 Regulation of the estrogen receptor in MCF-7 cells by estradiol. Mol Endocrinol 2:1157-1162

27. Saceda M, Lippman ME, Lindsey RK, Puente $M$, Martin MB 1989 Role of an estrogen receptor-dependent mechanism in the regulation of estrogen receptor mRNA in MCF-7 cells. Mol Endocrinol 3:1782-1787

28. Alexander IE, Clarke CL, Shine J, Sutherland RL 1989 Progestin inhibition of progesterone receptor gene expression in human breast cancer cells. Mol Endocrinol 3:1377-1386

29. Kaufman M, Pinsky L, Feder-Hollander R 1981 Defective up-regulation of the androgen receptor in human androgen insensitivity. Nature 293:735-737

30. Gad YZ, Berkovitz GD, Migeon CJ, Brown TR 1988 Studies of up-regulation of androgen receptors in genital skin fibroblasts. Mol Cell Endocrinol 57:205-213

31. Wolf DA, Schulz P, Fittler F 1992 Transcriptional regula- 
tion of prostate kallikrein-like genes by androgen. Mol Endocrinol 6:753-762

32. Horoszewicz JS, Leong SS, Kawinski E, Karr JP, Rosenthal H, Chu TM, Mirand EA, Murphy GP 1983 LNCaP model of human prostatic carcinoma. Cancer Res 43:1809-1818

33. Akimoto S, Fuse H, Sato R, Zama S, Shimazaki J 1985 Binding of mibolerone to androgen receptor of benign hypertrophic human prostate. Comparison with R1881. Endocrinol Jpn 32:141-152

34. Wolf DA, Kohlhuber F, Schulz P, Fittler F, Eick D 1992 Transcriptional down-regulation of c-myc in human prostate carcinoma cells by the synthetic androgen mibolerone. Br J Cancer 65:376-382

35. Wolf DA, Schulz P, Fittier F 1991 Synthetic androgens suppress the transtormed phenotype in the human prostate carcinoma cell line LNCaP. Br J Cancer 64:47-53

36. Wakeling AE, Furr BJ, Glen AT, Hughes LR 1981 Receptor binding and biological activity of steroidal and nonsteroidal antiandrogens. J Steroid Biochem 15:355-359

37. Berger FG, Loose D, Meisner H, Watson G 1986 Androgen induction of messenger RNA concentrations in mouse kidney is posttranscriptional. Biochemistry 25:1170-1175

38. Page MJ, Parker MG 1982 Effect of androgen on the transcription of rat prostatic binding protein genes. Mol Cell Endocrinol 27:343-355

39. Zegers ND, Claassen E, Neelen C, Mulder E, van Laar $\mathrm{JH}$, Voorhorst MM, Berrevoets CA, Brinkmann AO, van der Kwast TH, Ruizeveld de Winter JA, Trapman J, Boersma WJA 1991 Epitope prediction and confirmation for the human androgen receptor: generation of monoclonal antibodies for multiassay performance following the synthetic peptide strategy. Biochem Biophys Res Commun 1073:23-29

40. van Laar JH, Bolt de Vries J, Voorhorst Ogink MM, Brinkmann AO 1989 The human androgen receptor is a $110 \mathrm{kDa}$ protein. Mol Cell Endocrinol 63:39-44

41. Challis JRG, Kim CK, Naftolin F, Judd HL, Yen SSC, Benirschke K 1974 The concentration of androgens, oestrogens, progesterone and luteinizing hormone in the serum of foetal calves throughout the course of gestation. $\mathrm{J}$ Endocrinol 60:107-112

42. Schramm $P$, Gudat $W$, Benes $P 1990$ Circulating androgens in men with acne. Arch Dermatol Res 282:475-476

43. Kemppainen JA, Lane MV, Sar M, Wilson EM 1992 Androgen receptor phosphorylation, tumover, nuclear transport, and transcriptional activation-specificity for steroids and antihormones. J Biol Chem 267:968-974

44. Stone KR, Mickey DD, Wunderli H, Mickey GH, Paulson DF 1978 Isolation of a human prostate carcinoma cell line (DU 145). Int J Cancer 21:274-281

45. Schüle R, Müller M, Kaltschmidt C, Renkawitz R 1988 Many transcription factors interact synergistically with steroid receptors. Science 242:1418-1420

46. LeClerc S, Palaniswami R, Xie BX, Govindan MV 1991 Molecular cloning and characterization of a factor that binds the human glucocorticoid receptor gene and represses its expression. J Biol Chem 266:17333-17340

47. LeClerc S, Xie BX, Roy R, Govindan MV 1991 Purification of a human glucocorticoid receptor gene promoter-binding protein. Production of polycional antibodies against the purified factor. J Biol Chem 266:8711-8719

48. Deleted in proof

49. Baarends WM, Themmen AP, Blok LJ, Mackenbach P Brinkmann AO, Meijer D, Faber PW, Trapman J, Grootegoed JA 1990 The rat androgen receptor gene promoter. Mol Cell Endocrinol 74:75-84

50. Sassone Corsi $P$, Sisson JC, Verma IM 1988 Transcriptional autoregulation of the proto-oncogene fos. Nature 334:314-319

51. König H, Ponta $H$, Rahmsdorf U, Buscher $M$, Schönthal
A, Rahmsdorf HJ, Herrlich P 1989 Autoregulation of fos: the dyad symmetry element as the major target of repression. EMBO J 8:2559-2566

52. Lucibello FC, Lowag C, Neuberg M, Müller R 1989 Transrepression of the mouse c-fos promoter: a novel mechanism of Fos-mediated trans-regulation. Cenl 59:999-1007

53. Shaw PE, Frasch S, Nordheim A 1989 Repression of $c-$ fos transcription is mediated through p67SRF bound to the SRE. EMBO J 8:2567-2574

54. Yang Yen HF, Chambard JC, Sun YL, Smeal T, Schmidt TJ, Drouin J, Karin M 1990 Transcriptional interference between c-Jun and the glucocorticoid receptor: mutual inhibition of DNA binding due to direct protein-protein interaction. Cell 62:1205-1215

55. Veldscholte J, Voorhorst Ogink MM, Bolt de Vries J, van Rooij HC, Trapman J, Mulder E 1990 Unusual specificity of the androgen receptor in the human prostate tumor cell line LNCaP: high affinity for progestagenic and estrogenic steroids. Biochim Biophys Acta 1052:187-194

56. Veldscholte J, Ris Stalpers C, Kuiper GG, Jenster G, Berrevoets C, Claassen E, van Rooij HC, Trapman J, Brinkmann AO, Mulder E 1990 A mutation in the ligand binding domain of the androgen receptor of human $\mathrm{LNCaP}$ cells affects steroid binding characteristics and response to anti-androgens. Biochem Biophys Res Commun 173:534-540

57. Veldscholte J, Berrevoets CA, Brinkmann AO, Grootegoed JA, Mulder E 1992 Antiandrogens and the mutated androgen receptor of LNCaP cells-differential effects on binding affinity, heat-shock protein interaction, and transcription activation. Biochemistry 31:2393-2399

58. Riegman PHJ, Vietstra RJ, Vanderkorput JAGM, Brinkmann AO, Trapman J 1991 The promoter of the prostatespecific antigen gene contains a functional androgen responsive element. Mol Endocrinol 5:1921-1930

59. Berns EM, de Boer W, Mulder E 1986 Androgen-dependent growth regulation of and release of specific protein(s) by the androgen receptor containing human prostate tumor cell line LNCaP. Prostate 9:247-259

60. van Laar JH, Berrevoets CA, Trapman J. Zegers ND, Brinkmann AO 1991 Hormone-dependent androgen receptor phosphorylation is accompanied by receptor transformation in human lymph node carcinoma of the prostate cells. J Biol Chem 266:3734-3738

61. Keydar I, Chen L, Karby S, Weiss FR, Delarea J, Radu M, Chaitcik S, Brenner HJ 1979 Establishment and characterization of a cell line of human breast carcinoma origin. Eur J Cancer 15:659-670

62. Allen RW, Trach KA, Hoch JA 1987 Identification of the $37-\mathrm{kDa}$ protein displaying a variable interaction with the erythroid cell membrane as glyceraldehyde-3-phosphate dehydrogenase. J Biol Chem 262:649-653

63. Tilley WD, Marcelli M, Wilson JD, McPhaul MJ 1989 Characterization and expression of a cDNA encoding the human androgen receptor. Proc Natl Acad Sci USA 86:327-331

64. Schulz P, Stucka R, Feldmann H, Combriato G, Klobeck $H G$, Fittler $F 1988$ Sequence of a cDNA clone encompassing the complete mature human prostate specific antigen (PSA) and an unspliced leader sequence. Nucleic Acids Res 16:6226

65. Michelson AM, Markham AF, Orkin SH 1983 Isolation and DNA sequence of a full-length cDNA clone for human $X$ chromosome-encoded phosphoglycerate kinase. Proc Natl Acad Sci USA 80:472-476

66. Berk AJ, Sharp PA 1977 Sizing and mapping of early adenovirus mRNAs by gel electrophoresis of $\mathrm{S} 1$ endonuclease-digested hybrids. Cell 12:721-730

67. Sambrook J, Fritsch EF, Maniatis T 1989 Molecular Cloning: a Laboratory Manual, ed 2. Cold Spring Harbor Laboratory Press, Cold Spring Harbor, NY 